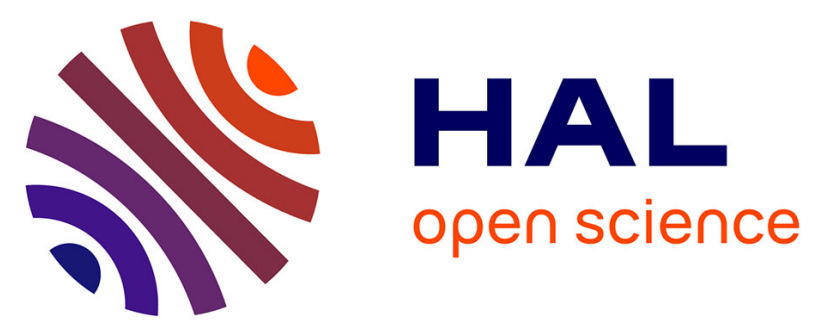

\title{
Mechanism of water adsorption in the large pore form of the gallium-based MIL-53 metal-organic framework
}

Guy Weber, Igor Bezverkhyy, Jean-Pierre Bellat, Anthony Ballandras, Guillaume Ortiz, Gérald Chaplais, Joël Patarin, François-Xavier Coudert, Alain Fuchs, Anne Boutin

\section{To cite this version:}

Guy Weber, Igor Bezverkhyy, Jean-Pierre Bellat, Anthony Ballandras, Guillaume Ortiz, et al.. Mechanism of water adsorption in the large pore form of the gallium-based MIL-53 metal-organic framework. Microporous and Mesoporous Materials, 2016, 222, pp.145-152. 10.1016/j.micromeso.2015.10.003 . hal-02116279

\section{HAL Id: hal-02116279 \\ https://hal.science/hal-02116279}

Submitted on 30 Apr 2019

HAL is a multi-disciplinary open access archive for the deposit and dissemination of scientific research documents, whether they are published or not. The documents may come from teaching and research institutions in France or abroad, or from public or private research centers.
L'archive ouverte pluridisciplinaire HAL, est destinée au dépôt et à la diffusion de documents scientifiques de niveau recherche, publiés ou non, émanant des établissements d'enseignement et de recherche français ou étrangers, des laboratoires publics ou privés. 


\title{
Mechanism of Water Adsorption in the Large Pore Form of the
}

\section{Gallium-Based MIL-53 Metal Organic Framework}

\author{
Guy Weber $^{*, \dagger}{ }^{\dagger}$ Igor Bezverkhyy ${ }^{\dagger}$, Jean-Pierre Bellat ${ }^{\dagger}$, Anthony Ballandras ${ }^{\dagger}$, \\ Guillaume Ortiz ${ }^{\ddagger}$, Gérald Chaplais ${ }^{\ddagger}$, Joël Patarin ${ }^{\ddagger}$, François-Xavier Coudert ${ }^{\S}$, Alain \\ H. Fuchs ${ }^{\S}$, Anne Boutin ${ }^{\perp}$ \\ ${ }^{\dagger}$ Laboratoire Interdisciplinaire Carnot de Bourgogne (ICB), UMR 6303 CNRS-Université \\ de Bourgogne Franche-Comté, 9 av. Alain Savary, BP 47870, F- 21078 Dijon Cedex, \\ France
}

‡Université de Strasbourg (UdS), Université de Haute Alsace (UHA), CNRS, Équipe Matériaux à Porosité Contrôlée (MPC), Institut de Science des Matériaux de Mulhouse (IS2M), UMR 7361, 3 bis rue Alfred Werner, F- 68093 Mulhouse Cedex, France

${ }^{\S}$ PSL Research University, Chimie ParisTech - CNRS, Institut de Recherche de Chimie Paris, F- 75005 Paris, France

${ }^{\perp}$ École Normale Supérieure, PSL Research University, Département de Chimie, Sorbonne Universités - UPMC Univ Paris 06, CNRS UMR 8640 PASTEUR, 24 rue Lhomond, F75005 Paris, France

\footnotetext{
* Corresponding author. Tel.: +33 380396 145; fax: +33 380396132.

E-mail address: guy.weber@u-bourgogne.fr
} 


\begin{abstract}
Water adsorption in the large (lp_empty) pore form of Ga-MIL-53 was studied by TGA, DSC and in situ XRD and FTIR at $298 \mathrm{~K}$. The large pore form can be stabilized at room temperature after activation under vacuum at $553 \mathrm{~K}$. The isotherm of water adsorption in this large pore form (pore dimensions: $1.67 \times 1.33 \mathrm{~nm}$ ) is very similar to that measured on the narrow (np_empty) pore form (pore dimensions: $1.97 \times 0.76 \mathrm{~nm}$ ). Such a similarity is rather unusual given that the pore sizes of these two phases are very different. In order to understand the origin of this effect in situ XRD and FTIR measurements were particularly helpful. It was found that the adsorption of even small amount of water $(0.05$ mol per $\mathrm{Ga}$ atom at $0.2 \mathrm{hPa}$ ) in the large pore form of Ga-MIL-53 transforms ca. $50 \%$ of the solid into a narrow pore int phase, which is assumed to be present as a shell around the lp_empty core. Additional water molecules adsorbed at higher pressures do not interact with the parent $l p \_e m p t y$ phase but with the narrow pore int phase. The phase transformations were confirmed by FTIR revealing significant band displacements in the corresponding pressure ranges. Such easy pore shrinking which occurs at very low water pressure $(<0.2 \mathrm{hPa})$ can have undesirable consequences in working conditions, as for example in separation adsorption processes, because the large pore structure of Ga-MIL-53 can be preserved only under anhydrous conditions.
\end{abstract}

\title{
Keywords
}

Water, adsorption, MIL-53, gallium, phase transition 


\section{Introduction}

Metal-organic frameworks (MOFs), which are a relatively new class of nanoporous materials, have attracted foremost attention in recent past owing to their intriguing structural topologies and promising applications in a wide range of areas including gas storage/separation [1-6], catalysis [7, 8] and drug delivery [9-12]. Built up from inorganic building units and organic linkers, MOFs form porous structures with 1-D, 2-D, or 3-D channel systems [13-22].

Among the various porous MOFs, the terephthalate based MOFs M-MIL-53 [M(III): Al, $\mathrm{Cr}, \mathrm{Fe}, \mathrm{Ga}, \mathrm{Sc}, \mathrm{In}]$ are well-studied because of their large potential applications [10, 14, 2331]. Their frameworks [14, 28, 32-44] consist of infinite trans corner-sharing $\left[\mathrm{M}(\mathrm{III}) \mathrm{O}_{4}(\mathrm{OH})_{2}\right]$ octahedra chains interconnected by terephthalate linkers, resulting in a one-dimensional rhombic-shaped channel system with pores of free diameter close to 0.85 $\mathrm{nm}$ in their large pore form. Different representations of the channel openings for Ga-MIL53 can be seen in previous publications [31, 44-46].

These soft porous crystals exhibit exceptional flexibility sometimes called "breathing" which is often attributed to the presence of $\mu_{2}-\mathrm{OH}$ groups in the frameworks but the torsion angles of the linker as its connection to the metal take also a significant part in the phenomenon [28, 32, 39, 42, 47]. The reversible structural flexibility of M-MIL-53 strongly depends, of course, on the incorporated metal ion, and the size and functionality of the linker molecules $[30,31,41,48-62]$. The conditions at which the breathing happens have been widely described in the literature and it was shown that the structural transformation is 
triggered by adsorption of single gases (e.g., $\mathrm{CO}_{2}$, linear alkanes, xylenes...) and mixtures $[14,24,26,28,33,39,40,42,63-74]$, by mechanical constraints $[34,75-78]$, or by changes in temperature $[31,32,46,66,79]$. This reversible structural transition occurs between a narrow pore $(n p)$ and large pore $(l p)$ form and can result in a change in unit cell volume up to $40 \%$. This flexibility confers to these materials interesting adsorption properties and consequently they can find new applications in the field of gas separation or storage by adsorption.

However, for industrial applications the hydrothermal stability of these materials needs still to be improved $[80,81]$. New MOFs having a better stability in working conditions could not be elaborated without a detailed knowledge of the interaction mechanism between water and these nanoporous materials. Interestingly, relatively few studies are devoted to the interaction of water on MIL-53 [14, 33, 50, 52, 53, 56, 80, 82-96] especially on gallium-based MIL-53 [31, 44-46, 97]. Moreover, the effect of the temperature of outgassing on the adsorption process has never been studied.

Such a study is even more needed due to the atypical behavior of gallium compared to the aluminum or chromium analogs $[31,45,46,97]$. Indeed, in a recent paper we showed that, under vacuum and at room temperature, the narrow pore form (np_empty) [97] is thermodynamically more stable for Ga-MIL-53 contrary to what is observed for Al-MIL-53 and Cr-MIL-53 [31, 46], where the large pore form (lp_empty) is favored at room temperature [46]. The monoclinic $n p \_$empty $\rightarrow$ orthorhombic lp_empty phase transition for the gallium-based MIL-53 occurs at a higher temperature $(553 \mathrm{~K})$ than it does for the aluminum or chromium analogs. Moreover, the large pore form can be stabilized by 
quenching the material at room temperature. In a more recent study [97], we showed by combining adsorption measurements and molecular calculations that the hydration of GaMIL-53 from the $n p \_e m p t y$ phase to the $n p_{-} H_{2} O$ phase occurs via the formation of an intermediate int phase. This intermediate phase has the same monoclinic structure as the np_empty phase, but the unit cell parameters are slightly different. The coexistence of both int and $n p_{-} \mathrm{H}_{2} \mathrm{O}$ phases in an intermediate pressure domain has an effect on the adsorption process of water and explains why the adsorption isotherm shows a step in the loading domain 0.05-0.2 mol.mol ${ }^{-1}$ at $298 \mathrm{~K}$ [97]. The hydration of the lp_empty phase was not studied though it is essential to know if the interaction of water with the large pore form is the same as that with the narrow pore one.

The present study concerns the interaction of water with a Ga-MIL-53 material outgassed at high temperature (large pore form, lp_empty) before adsorption measurements at $298 \mathrm{~K}$.

It is well known that the large pore MIL-53 phases transform into narrow pore hydrated phases under high water vapor pressure, but little is known about the precise location of this phase transition, and no more about the existence domain of the large pore structure of GaMIL-53. Such information are of prime importance for potential applications.

Experiments were performed combining different experimental techniques such as TGA, DSC, in situ XRD and in situ FTIR under controlled temperature and water vapor pressure. Results are analyzed and compared with those obtained for the Ga-MIL-53 material 
outgassed at low temperature (narrow pore form, np_empty). Finally, we propose an adsorption mechanism of water on this type of materials.

\section{Experimental}

\subsection{Synthesis}

All reagents and chemicals were used without any further purification. The metal source, gallium nitrate hydrate $\mathrm{Ga}\left(\mathrm{NO}_{3}\right)_{3} \cdot \mathrm{xH}_{2} \mathrm{O}(99.99 \%)$, was purchased from Strem Chemicals. The organic linker source, terephthalic acid $\left(\mathrm{H}_{2} \mathrm{BDC}, 99 \%\right)$ was supplied by Fluka. The solvents, $N, N$-dimethylformamide (DMF, $\geq 99 \%$ ) and ethanol (EtOH, $\geq 99.8 \%)$, were provided by Sigma-Aldrich and VWR, respectively. Hydrofluoric acid (HF, $40 \%$ ) was purchased from Prolabo.

Crude form of Ga-MIL-53 (i.e. Ga-MIL-53_lp_H2BDC) was hydrothermally prepared from a mixture of $\mathrm{Ga}\left(\mathrm{NO}_{3}\right)_{3} \cdot \mathrm{x} \mathrm{H}_{2} \mathrm{O}(8.19 \mathrm{~g} ; 32.05 \mathrm{mmol}$ by assuming $\mathrm{x}=0), \mathrm{H}_{2} \mathrm{BDC}(10.64$ $\mathrm{g} ; 64.04 \mathrm{mmol})$, HF (1.60 g; $32.05 \mathrm{mmol})$ in deionized water in 1/2/1/100 molar ratio. The mixture was heated at $493 \mathrm{~K}$ for 3 days in a Teflon ${ }^{\circledR}$-lined stainless steel autoclave. The solid was filtered, washed with hot DMF (in order to remove the unreacted molecules of $\mathrm{H}_{2} \mathrm{BDC}$ ), ethanol and dried at room temperature. Large white crystals were obtained with a yield of $49 \%$ based on $\mathrm{Ga}(5.35 \mathrm{~g} ; 14.25 \mathrm{mmol})$. Then, the as-made material was treated with DMF (weight ratio DMF/Ga-MIL-53_lp_H ${ }_{2} \mathrm{BDC}:$ 75) in a Teflon ${ }^{\circledR}$-lined stainless steel autoclave at $433 \mathrm{~K}$ for 6 days. The solid (i.e. Ga-MIL-53_lp_DMF) was recovered by filtration, washed with DMF and dried at room temperature. Finally, Ga-MIL-53_np_ $\mathrm{H}_{2} \mathrm{O}$ was obtained from Ga-MIL-53_lp_DMF after removal of DMF by keeping the solid in 
suspension in EtOH at room temperature during $24 \mathrm{~h}$. After filtration, the white crystals were heated in air at $548 \mathrm{~K}$ for 1 day. After cooling down, a white crystalline powder was recovered with the chemical formula $\mathrm{Ga}(\mathrm{OH})_{0.9}(\mathrm{~F})_{0.1}(\mathrm{BDC}) \cdot 0.9 \mathrm{H}_{2} \mathrm{O}$.

The amount of fluorine (molar F/Ga ratio of $0.10 \pm 0.04$ ) in Ga-MIL-53_np_ $\mathrm{H}_{2} \mathrm{O}$ was evaluated by ${ }^{19} \mathrm{~F}$ NMR using $\mathrm{CF}_{3} \mathrm{COOH}$ as internal standard after digestion of the material in a NaOD solution. The procedure has been fully described in our previous work [46].

On the other hand, the water content and the rest of the chemical composition were determined from thermal analysis carried out under air by considering the weight losses from room temperature to $473 \mathrm{~K}$ for water content and from 473 to $1073 \mathrm{~K}$ for the rest of the chemical composition. This detailed analysis reported in Ref. [44] allowed to dismiss the presence of unreacted organic source and solvent ( $N, N$-dimethylformamide).

In addition, XRD characterizations and nitrogen adsorption measurements at $77 \mathrm{~K}$ were also performed to verify that the heat treatment and the exposure to air i.e. under a water vapor pressure of around $12 \mathrm{hPa}$ (approximatively $40 \%$ of relative humidity) for a long time ( 2 years) did not affect significantly the crystalline structure and the porosity of GaMIL-53 (see Figs. S1-S2 in supporting information). Under these conditions, Ga-MIL-53 shows a quite good stability in presence of water vapor. Of course this material is not stable in liquid water and it completely decomposes at room temperature.

Moreover, it can be noticed that the presence of fluorine with a molar F/Ga ratio of 0.1 renders Ga-MIL-53 a little more hydrophobic. However, as far as can be determined from 
the available data, no conclusion can be drawn concerning its influence on the mechanism of water adsorption on Ga-MIL-53.

\subsection{Thermogravimetry}

Adsorption-desorption isotherm of water on Ga-MIL-53 outgassed at $553 \mathrm{~K}$ under vacuum $\left(10^{-5} \mathrm{hPa}\right)$ overnight was measured at $298 \mathrm{~K}$ by using a McBain thermobalance constructed in house. The water vapor pressure was ranging from $10^{-5}$ to $30 \mathrm{hPa}$. The sample weight was about $15 \mathrm{mg}$. More details can be found elsewhere [97-100]. The

experimental error estimated on the adsorbed amount is about $10^{-3} \mathrm{~g} \cdot \mathrm{g}^{-1}$. This corresponds to around 0.02 molecule of water per mole of adsorbent. The accuracy on the pressure data is $1 \%$ and the temperature is measured with a precision of $1 \mathrm{~K}$.

\subsection{X-ray diffraction}

The XRD patterns of Ga-MIL-53 were recorded under controlled water pressure using the in situ capillary technique. To realize the measurements the hydrated Ga-MIL-53 sample was sieved and placed in a Pyrex capillary of $0.5 \mathrm{~mm}$ external diameter. The capillary was connected to a McBain thermobalance which contained the same sample in the measurement pan. Given that both samples (inside the capillary and in the measurement pan) were exposed to the same atmosphere at the same temperature, measuring the weight of one of them allowed us to determine the amount of water adsorbed on the sample placed in the capillary.

After outgassing at room temperature under a pressure of $10^{-5} \mathrm{hPa}$ the sample was heated up to $553 \mathrm{~K}$ with a heating rate of $5 \mathrm{~K} \cdot \mathrm{min}^{-1}$ under dynamic vacuum and kept at this 
temperature for $15 \mathrm{~h}$. Then the sample was cooled to room temperature and exposed to a chosen pressure of water vapor created inside the thermobalance. Once the equilibrium was attained (usually after ca. $15 \mathrm{~h}$ ) the capillary was sealed off and the XRD pattern of the

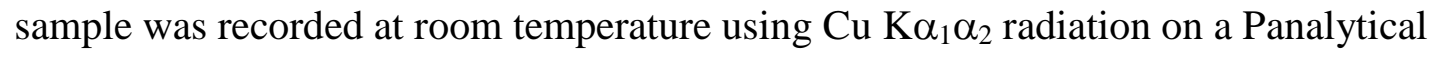
Empyrean diffractometer. The unit cell parameters of the different phases were determined using Le Bail full pattern decomposition implemented in the FullProf software package $[101,102]$. Although the atomic structure of the large pore phase of Ga-MIL-53 is not known, its pattern can be indexed in an orthorhombic system [45]. We chose therefore the space group Pmmm to represent the large pore phase of Ga-MIL-53 in the pattern decomposition. For the partially hydrated Ga-MIL-53 (so called the int phase) the group space $\mathrm{C} c$ was used since the fully hydrated phase crystallized in this space group [46].

\subsection{Differential calorimetry}

Adsorption enthalpy of water vapor on Ga-MIL-53 was measured with a differential calorimeter (Tian-Calvet Setaram C80) coupled with a manometric homemade apparatus. Further details about the device and the experimental procedure were reported elsewhere [103]. It allows measuring the molar adsorption enthalpy $\Delta H^{a}\left(n^{a}\right)$ of water, also called the adsorption heat $Q^{a}$, as a function of the adsorbed amount $n^{a}$. Adsorption was performed at $298 \mathrm{~K}$ on about $300 \mathrm{mg}$ of material. Prior to adsorption, Ga-MIL-53 was outgassed under vacuum at $10^{-5} \mathrm{hPa}$ overnight at $553 \mathrm{~K}$. The water vapor pressure ranged from 0.1 to 25 $\mathrm{hPa}$. The error on the adsorption enthalpy was estimated to be around $\pm 2 \mathrm{~kJ} \cdot \mathrm{mol}^{-1}$. 


\subsection{In situ Infrared Spectroscopy}

In situ FTIR absorption measurements were performed in an optical cell specially built to study the interaction of a gas on a nanoporous material under controlled vapor pressure. The experimental set-up has been detailed in previous recent papers [104, 105]. The FTIR spectrometer was a Bruker Equinox 55 instrument equipped with a globar source, a DTGS detector and a $\mathrm{KBr}$ beamsplitter. All spectra were recorded in transmission mode over the wavenumber domain $4000-400 \mathrm{~cm}^{-1}$ at room temperature, with a resolution of $2 \mathrm{~cm}^{-1}$ and an average of 40 scans per analysis.

The procedure used for adsorption measurements consisted first in the activation of around 1-2 mg of powdered sample deposited in between two $\mathrm{KBr}$ pellets. Afterwards, the sample was outgassed at $553 \mathrm{~K}$ under dynamic vacuum $\left(10^{-5} \mathrm{hPa}\right)$ in the heat chamber. Then, after cooling to room temperature, adsorption measurements were performed at the equilibrium, by increasing water vapor pressure, step by step [104, 105]. Each spectrum of the powdered sample was recorded under equilibrium conditions at constant pressure from $\mathrm{P}=10^{-4} \mathrm{hPa}$ to about $30 \mathrm{hPa}$. Spectra obtained after activation and adsorption were referenced to background spectra recorded in the same conditions, but without sample.

\section{Results and discussion}

\subsection{Adsorption-desorption isotherms at 298 K. Effect of the activation temperature}

Fig. 1 shows the adsorption-desorption isotherms of water on the narrow and large pore forms of Ga-MIL-53, over the pressure range 0-2 $\mathrm{hPa}$. The complete isotherms are presented in Fig. S3 in supporting information. One significant feature of the isotherm 
obtained after Ga-MIL-53 was activated at $553 \mathrm{~K}$ is that the adsorption branch coincides with the desorption branch within the explored pressure range, indicating that the adsorption phenomenon is reversible. It is worth noting that the same observation was made for the water adsorption desorption isotherm measured on Ga-MIL-53 outgassed at room temperature [97]. The fact that the adsorption and desorption branches of the isotherms are superposable indicate that the material does not, or very slightly, degrade after the first adsorption desorption cycle. The few adsorption measurements which were performed to test the stability of Ga-MIL-53 after the first adsorption desorption cycle, do not even indicate any significant variation of the adsorption capacity of the sample at any water pressure.

[insert Fig. 1]

Another interesting feature is that the shape of this adsorption-desorption isotherm is strongly similar to that of the water adsorption isotherm obtained on the narrow pore form of Ga-MIL-53 activated at room temperature [97]. In addition, only very small differences in the amounts of water adsorbed at any given pressure are noticeable between the lp_empty and $n p \_e m p t y$ forms of Ga-MIL-53.

The water adsorption isotherms obtained on the large and narrow pore forms of GaMIL-53 can be schematically described considering three distinct loading domains, each of them being characterized by a step, when the water pressure increases (Fig. 1). In the domain $\mathrm{I}(\mathrm{P}<0.4 \mathrm{hPa})$, the curve exhibits an initial increase up to $0.14 \mathrm{hPa}$ then it attains a plateau region corresponding to an amount of water adsorbed of ca. $0.05 \mathrm{~mol}_{\mathrm{mol}}{ }^{-1}$. In the domain II $(0.40<\mathrm{P}<0.65 \mathrm{hPa})$ the isotherm displays a continuous increase in the amount 
adsorbed from 0.05 mol. $\mathrm{mol}^{-1}$ to about $0.2 \mathrm{~mol} . \mathrm{mol}^{-1}$. Lastly, in the domain III $(\mathrm{P}>0.65$

$\mathrm{hPa}$ ) the curve shows a vertical step then a continuous increase in the amount adsorbed up to 0.9 mol.mol ${ }^{-1}$ on approaching the saturation water vapor pressure.

At first sight, we can assume that both samples show the same overall behavior during the adsorption process because of the similar shape of water adsorption isotherms obtained on Ga-MIL-53 activated at 298 and $553 \mathrm{~K}$. This similarity is rather surprising given that the initial structures of these two phases are very different.

\subsection{Structural characterization of the phases formed during the hydration process}

The XRD patterns of Ga-MIL-53 activated at $553 \mathrm{~K}$ then exposed to increasing water pressures, successively at $0.2,0.5,0.8$ and $15 \mathrm{hPa}$ are given in Fig. 2. Another representation of these diffraction patterns allowing an easier comparison of the evolution of the position and the intensity of diffraction peaks over three different $2 \theta$ angular ranges is shown in Figs. S4-S6 in supporting information.

[insert Fig. 2]

The exposure of the lp_empty form of Ga-MIL-53 to water vapor pressures at 0.2, 0.5, 0.8 and $15 \mathrm{hPa}$ results in the decrease of the intensities of the peaks characteristic of lp_empty (see the evolution of the (110) and (020) peaks in Fig. S4, and, that of the (011), (220) and (301) peaks in Fig. S6 in supporting information). The residual amounts of the lp_empty phase at $0.2,0.5,0.8$ and $15 \mathrm{hPa}$ were calculated from the ratio of the area of a given diffraction peak of the lp_empty phase to the area of the same diffraction peak in the pure $l p \_e m p t y$ phase (large pore form at zero loading). The averaged values determined 
from the (110), (020), (011), (220) and (301) diffraction peaks of the lp_empty phase located at $8.5,10.5,14.7,17.0$ and $17.3^{\circ}(2 \theta)$, respectively, are given in Table 1 . These ratios give a good estimation of the amount of the lp_empty phase in each sample analyzed at a given pressure because all involved phases of close composition may be considered to have similar absorption coefficients [106].

\section{[insert Table 1]}

Water adsorption results also in the appearance of new peaks whose intensities grow with water pressure (see the evolution of the (110) peak labelled B for the $n p_{-} H_{2} \mathrm{O}$ phase and A for the int phase in Fig. S5). The shift of the A and B diffraction peak positions with increasing pressure accounts for an increase of the unit cell parameter $b$ consecutive to the adsorption of additional water molecules in the pores of the $n p_{-} H_{2} \mathrm{O}$ and int phases (Table 1, Fig. S5).

Exposure to $0.2 \mathrm{hPa}$ of water results in the transformation of ca. $52 \%$ of the dehydrated solid into the int phase, which is characterized in particular by the presence of an additional peak at $13.5^{\circ}$ in the diffraction pattern (Peak A in Figs. 2b and S5 in supporting information). It should be specified that this int phase was also observed upon the partial hydration of the $n p \_$empty phase for water loading below $0.2 \mathrm{~mol}_{\mathrm{mol}} \mathrm{m}^{-1}$ and that it transforms into the $n p_{-} \mathrm{H}_{2} \mathrm{O}$ phase at higher loadings [97]. The structure of the int phase is the same as that of the $n p \_$empty phase, notwithstanding a slightly higher value of the unit cell parameter $b$ due to the presence of water molecules in the pores [97]. It is worth noting that despite a low amount of water adsorbed at $0.2 \mathrm{hPa}\left(0.05 \mathrm{~mol}^{\mathrm{mol}} \mathrm{m}^{-1}\right.$, see Fig. 1$)$, half of the solid is transformed into a narrow pore form. 
Further increase in pressure up to $0.5 \mathrm{hPa}$ results in almost complete transformation of the int phase into the $n p_{-} H_{2} \mathrm{O}$ phase inducing a strong decrease of the intensity of the (110) peak of the intermediate narrow pore phase (Peak A in Figs. 2c and S5 in supporting information). Besides it should be noticed that the lp_empty phase does not change significantly when the water pressure increases from 0.2 to $0.5 \mathrm{hPa}$ (Table 1).

Finally, after exposure to $0.8 \mathrm{hPa}$ of water, the solid (lp_empty phase) further transforms into the $n p \_H_{2} \mathrm{O}$ phase which becomes the unique phase at higher pressures (Figs. 2d-e and S4-S6 in supporting information).

\subsection{Energetic characterization of the adsorption process}

While water adsorption isotherms measured at $298 \mathrm{~K}$ on the $n p \_e m p t y$ and lp_empty forms are overall the same, the corresponding adsorption enthalpy curves (where the adsorption enthalpy is given in absolute value) show slight differences at low loading ( $n^{a}<$ $0.2 \mathrm{~mol}_{\mathrm{mol}}{ }^{-1}$ ), i.e. in the domain of existence of the two first steps in the adsorption isotherms (Figs. 1, 3).

[insert Fig. 3]

First, whatever may be the activation temperature of Ga-MIL-53, the enthalpy of adsorption at zero loading $\left(32 \mathrm{~kJ} \mathrm{~mol}^{-1}\right)$ is lower than the enthalpy of liquefaction of water $\left(44 \mathrm{~kJ} . \mathrm{mol}^{-1}\right)$. This result is indicative of a same hydrophobic nature of the $n p \_$empty and lp_empty phases in accordance with the shape of the adsorption isotherms.

For the adsorbent activated at $298 \mathrm{~K}$ (np_empty form) a sharp increase of the enthalpy is observed in the range where the int phase forms $\left(n^{a}<0.05 \mathrm{~mol}^{\mathrm{mol}}{ }^{-1}\right)$ [97]. This increase is 
attributed to molecular interactions between water molecules which are extremely confined in channels of small size. Afterwards, the enthalpy curve decreases from 0.05 to 0.2 mol.mol ${ }^{-1}$. This decrease coincides with the $i n t \rightarrow n p_{-} H_{2} O$ phase transition and can be explained by weaker water-water interactions in this phase because water is less confined in pores slightly larger. Then, above ca. $0.2 \mathrm{~mol}^{\mathrm{mol}}{ }^{-1}$, the material is transformed into the $n p \_H_{2} O$ phase and the completion of the pore filling proceeds with almost constant enthalpy of adsorption. Finally, the enthalpy of adsorption decreases to the value of the enthalpy of liquefaction of water, when the channels are filled up.

The evolution of the heat curve for the sample activated at $553 \mathrm{~K}$ (lp_empty phase) is similar to that observed for the sample outgassed at room temperature (np_empty phase), except in the range of loadings below $0.2 \mathrm{~mol}^{\mathrm{mol}}{ }^{-1}$ (Fig. 3). A lower increase of the adsorption enthalpy of water is observed in the case of the lp_empty phase. This effect is due, on the one hand, to weaker water-water interactions because water is adsorbed in larger pores and, on the other hand, to the endothermic lp_empty - int phase transition $(\sim 50$ $\%$ of the lp_empty phase is transformed as observed in XRD studies). In this domain of loading the amounts of water adsorbed are so small, that the difference in behavior between the lp_empty and np_empty forms of Ga-MIL-53 cannot be detected by gravimetric measurements. Finally, above a loading of $0.2 \mathrm{~mol}_{\mathrm{mol}} \mathrm{m}^{-1}$, the heat curve for the lp_empty form is close to the one obtained for the np_empty form. This result is not surprising because the hydration of the lp_empty and np_empty forms leads to the formation of only one hydrated phase, i.e. $n p_{-} H_{2} O$, in this domain.

\subsection{Characterization of phase transitions by in situ infrared spectroscopy}


The adsorption of water on Ga-MIL-53 activated at $553 \mathrm{~K}$ (lp_empty form) or at room temperature (np_empty form) was also studied through in situ infrared spectroscopy. Infrared spectra were recorded, at first, free of adsorbate (activated state corresponding to the $n p \_e m p t y$ or $l p \_e m p t y$ form of the MOF) then, containing increasing amounts of water adsorbed under the equilibrium conditions. The analysis of spectra was performed by considering the modification of the position of vibrational bands during the adsorption process. The most significant results are shown in Figs. 4 and S7-S10 in supporting information.

[insert Fig. 4]

The infrared spectrum of the sample activated at high temperature (lp_empty form), is greatly modified during water adsorption. At least, six vibrational bands undergo a blue- or a red-shift. These wavenumber shifts may be significant as for example the ${ }_{\mathrm{as}} \mathrm{CO}_{2}$ asymmetric stretching vibration of the carboxylate group of the terephthalate moiety, which is shifted by $19 \mathrm{~cm}^{-1}$ (Fig. 4a). Here we report only vibrational modes which are the most perturbed upon adsorption. It is worth noting that wavenumber shifts occur within a narrow loading domain which depends on the mode of the vibration (Figs. 4 and S7-S10 in supporting information). All of them account for the coexistence of at least two phases within an intermediate restricted pressure domain.

The modes of vibration which are first perturbed at the lowest water vapor pressures are the in-plane $(\delta \mathrm{CH})$ and out-of-plane $(\gamma \mathrm{CH})$ deformation of the $\mathrm{CH}$ bonds of the benzene ring of the terephthalate ligands (Figs. 4b, 5 and S7-S8 in supporting information). The 
displacement of these vibrational bands is observed within a restricted pressure range from about 0.2 to $0.4 \mathrm{hPa}$ corresponding to an amount of water adsorbed of $0.05 \mathrm{~mol} . \mathrm{mol}^{-1}$, i.e. when the int phase is mainly formed.

The modes which are perturbed at higher water pressure $(\mathrm{P}>0.55 \mathrm{hPa}$, Fig. 5) are:

(i) the asymmetric stretching $v_{\mathrm{as}} \mathrm{CO}_{2}$ vibrations of the carboxylate groups of the terephthalate moiety (Fig. 4a),

(ii) the $\mathrm{vCC}$ ring stretching vibrations (referenced as $v 19 \mathrm{~A}$ in the Wilson notation [107]) of the terephthalate ligands (Fig. S9 in supporting information) and,

(iii) the symmetric stretching $\mathrm{v}_{\mathrm{s}} \mathrm{CO}_{2}$ vibrations of the carboxylate groups of the terephthalate ligands (Fig. S10 in supporting information).

The shift of these bands is observed over a pressure range $0.55-0.9 \mathrm{hPa}$ where the hydrated $n p \_H_{2} \mathrm{O}$ phase forms.

In comparison, the infrared spectrum of the sample activated at room temperature (np_empty form) is only slightly modified by water adsorption (Figs. 4 and S7-S10 in supporting information). Over the 17 bands identified in the spectrum, only the symmetric $v_{\mathrm{s}} \mathrm{CO}_{2}$ stretching vibrational band of the carboxylate groups is shifted by $2 \mathrm{~cm}^{-1}$ upon adsorption (Fig. S10 in supporting information). This shift occurs in a pressure range from about 0.6 to $0.9 \mathrm{hPa}$ corresponding to the domain of existence of the vertical step in the adsorption isotherm or to the domain of formation of the hydrated $n p \_H_{2} O$ phase. 
This study shows for the first time that in situ infrared spectroscopy can be used to identify the breathing phenomenon of Ga-MIL-53. The $i n t \rightarrow n p_{-} H_{2} O$ phase transition can be unequivocally identified considering the wavenumber shifts of characteristic vibrational bands, in particular those related to carboxylate vibrations. These functional groups of whose each O-O axis would act as a kneecap [28] during the reversible shrinkage are certainly the most affected when the structure shrinks.

\subsection{Overview of the mechanism of hydration of the large- and narrow-pore phases}

All experimental data obtained using macroscopic and microscopic approaches lead us to propose a mechanism of hydration of the Ga-MIL-53 material.

At first sight, one can infer that the mechanisms of interaction of water with the $n p \_$empty and lp_empty phases are very similar because water adsorption isotherms for both forms are very close. However, if we consider energetic data, it turns out that the large- and narrow-pore phases do not show the same behavior upon adsorption of the first water molecules.

For the adsorbent activated at room temperature, which exhibits a narrow pore $n p \_e m p t y$ structure the following adsorption mechanism was found in our previous study [97]. At low pressure, below $0.4 \mathrm{hPa}$, the water molecules are adsorbed in the pores forming the int phase which preserves the same structure with a small increase of the unit cell parameter $b$. At pressures higher than $0.8 \mathrm{hPa}$, this phase transforms into the $n p_{-} H_{2} O$ phase. We have shown by in situ XRD that, in this range of water pressure corresponding to the domain of existence of the second step in the isotherm, these two phases coexist. 
[insert Fig. 5]

For the adsorbent activated at $553 \mathrm{~K}$, i.e. for the sample having a large pore lp_empty structure, a possible mechanism of water adsorption may be discussed on the basis of the results obtained by XRD (Table 1, Fig. 5). The key finding in this context is the transformation of $52 \%$ of lp_empty into a narrow pore int phase occurring already at 0.2 $\mathrm{hPa}$ after adsorption of $0.05 \mathrm{~mol}$ of water per Ga atom. This result shows that the adsorption of even a small amount of water causes shrinkage of the pores in a substantial part of the solid. Surprisingly, an increase of water pressure from 0.2 to $0.5 \mathrm{hPa}$ does not result in further transformation of lp_empty (see Table 1), but into the hydration of the int counterpart. One possible cause for such behavior may be due to the formation of the int phase as a shell around the $l p \_e m p t y$ core at $0.2 \mathrm{hPa}$. On this assumption, the exposure of Ga-MIL-53 to $0.5 \mathrm{hPa}$ of water vapor pressure would result in further hydration of this shell (transformation $i n t \rightarrow n p \_H_{2} \mathrm{O}$ ) without influencing the structure of the $l p \_e m p t y$ core. It is only after saturation of the hydrated shell that water molecules could access to the interior of the particles resulting into further transformation of the lp_empty phase into the $n p \_\mathrm{H}_{2} \mathrm{O}$ phase at $0.8 \mathrm{hPa}$.

The assumption to consider the formation of a int shell around lp_empty at low water pressure would enable to explain also the striking similarity between the water adsorption isotherms obtained on the lp_empty and np_empty phases (Fig. 1). Indeed, once the shell would be formed, additional water molecules could not access to the lp_empty core and would be adsorbed in the narrow pores of the int phase. In other words, despite the presence of the lp_empty phase after activation at $553 \mathrm{~K}$, the "true" adsorbent after exposure to water 
vapor would be the int phase as in the case of the np_empty phase. Consequently, both isotherms are expected to be very similar, that is experimentally observed.

In the framework of this proposed mechanism, the IR spectroscopic data can be interpreted in the following way. The shifts of $\delta \mathrm{CH}$ and $\gamma \mathrm{CH}$ vibrations occur in the domain where int is the major phase. This implies that these shifts are due to the interaction between water molecules and benzene rings of the int phase. On increasing water loading the modification of the $v_{\mathrm{as}} \mathrm{CO}_{2}, v_{\mathrm{s}} \mathrm{CO}_{2}$ and $v \mathrm{CC}$ vibrations coincides with the transformation of the int phase into the $n p_{-} \mathrm{H}_{2} \mathrm{O}$ phase. The shift of these bands is therefore characteristic of the breathing phase transition.

\section{Conclusions}

We presented a detailed description of the mechanism of water adsorption on GaMIL-53, a flexible MOF exhibiting two stable adsorbate-free phases, either a large pore structure (lp_empty) or a narrow pore structure (np_empty). Despite the fact that the narrow pore phase is thermodynamically stable at $298 \mathrm{~K}$, we found that the large pore form obtained after heating under vacuum at $553 \mathrm{~K}$ can also be preserved at $298 \mathrm{~K}$. We characterized its interaction with water by TGA and calorimetry, as well as the occurrence of phase transformations upon water adsorption by in situ XRD and FTIR.

The most important feature revealed by the characterization techniques is the transformation of more than $50 \%$ of the parent lp_empty phase into a partially hydrated narrow pore phase (int) at low water loading $\left(0.05 \mathrm{~mol}^{\mathrm{mol}} \mathrm{l}^{-1}\right.$ at $\left.0.2 \mathrm{hPa}\right)$. It is worth noting

that this value is far below the water content $\left(0.9 \mathrm{~mol}^{\mathrm{mol}} \mathrm{l}^{-1}\right)$ of the fully hydrated Ga-MIL- 
53. Upon further increase of water loading up to $0.2 \mathrm{~mol}^{\mathrm{mol}}{ }^{-1}$ (at $0.5 \mathrm{hPa}$ ), the fraction of the lp_empty phase does not decrease significantly. The reaction proceeds through the hydration of the narrow pore int phase resulting in the formation of the $n p_{-} \mathrm{H}_{2} \mathrm{O}$ phase. This behavior hints that the int phase forms a shell which retains water molecules in its pores and hampers their access to the lp_empty core. Formation of such a narrow pore shell at low water pressure $(<0.2 \mathrm{hPa})$ explains the strong similarity between the water adsorption isotherms obtained on the narrow (np_empty) and large (lp_empty) pore forms of Ga-MIL53.

To the best of our knowledge the effect of pore shrinking in the large pore form of MIL53 type MOFs exposed to very low water pressure has not been described so far. Besides the academic interest to understand the mechanism of water adsorption, this phenomenon can have far reaching consequences in a context of application. Indeed the fact that even trace amounts of water $(<0.2 \mathrm{hPa})$ can provoke the pore shrinkage Ga-MIL-53 implies that any potential application requiring the use of the large pore form of MIL-53 has to be conducted under anhydrous conditions.

\section{Acknowledgments}

The authors are grateful for the financial support from the Agence Nationale de la Recherche under the project "SOFT-CRYSTAB" (ANR-2010-BLAN-0822).

\section{References}

[1] J.-R. Li, J. Sculley, H.-C. Zhou, Chem. Rev. 112 (2012) 869-932.

[2] Y.H. Hu, L. Zhang, Adv. Mater. 22 (2010) E117-E130.

[3] G. Férey, C. Serre, T. Devic, G. Maurin, H. Jobic, P.L. Llewellyn, G. De Weireld, A. Vimont, M. Daturi, J.-S. Chang, Chem. Soc. Rev. 40 (2011) 550-562. 
[4] K. Sumida, D.L. Rogow, J.A. Mason, T.M. McDonald, E.D. Bloch, Z.R. Herm, T.-H. Bae, J.R. Long, Chem. Rev. 112 (2012) 724-781.

[5] R.B. Getman, Y.-S. Bae, C.E. Wilmer, R.Q. Snurr, Chem. Rev. 112 (2011) 703-723.

[6] M.P. Suh, H.J. Park, T.K. Prasad, D.-W. Lim, Chem. Rev. 112 (2011) 782-835.

[7] J. Lee, O.K. Farha, J. Roberts, K.A. Scheidt, S.T. Nguyen, J.T. Hupp, Chem. Soc. Rev. 38 (2009) 1450-1459.

[8] P. Horcajada, S. Surble, C. Serre, D.-Y. Hong, Y.-K. Seo, J.-S. Chang, J.-M. Greneche, I. Margiolaki, G. Férey, Chem. Commun. (2007) 2820-2822.

[9] P. Horcajada, T. Chalati, C. Serre, B. Gillet, C. Sebrie, T. Baati, J.F. Eubank, D. Heurtaux, P. Clayette, C. Kreuz, J.-S. Chang, Y.K. Hwang, V. Marsaud, P.-N. Bories, L. Cynober, S. Gil, G. Férey, P. Couvreur, R. Gref, Nat. Chem. 9 (2010) 172-178.

[10] P. Horcajada, C. Serre, G. Maurin, N.A. Ramsahye, F. Balas, M. Vallet-Regí, M. Sebban, F. Taulelle, G. Férey, J. Am. Chem. Soc. 130 (2008) 6774-6780.

[11] P. Horcajada, C. Serre, M. Vallet-Regí, M. Sebban, F. Taulelle, G. Férey, Angew. Chem. Int. Ed. 45 (2006) 5974-5978.

[12] P. Horcajada, R. Gref, T. Baati, P.K. Allan, G. Maurin, P. Couvreur, G. Férey, R.E. Morris, C. Serre, Chem. Rev. 112 (2012) 1232-1268.

[13] M. Alhamami, H. Doan, C.H. Cheng, Materials 7 (2014) 3198-3250.

[14] T. Loiseau, C. Serre, C. Huguenard, G. Fink, F. Taulelle, M. Henry, T. Bataille, G. Férey, Chem. Eur. J. 10 (2004) 1373-1382.

[15] S.K. Ghosh, J.-P. Zhang, S. Kitagawa, Angew. Chem. Int. Ed. 46 (2007) 7965-7968.

[16] S. Kitagawa, R. Kitaura, S.-I. Noro, Angew. Chem. Int. Ed. 43 (2004) 2334-2375.

[17] J.L.C. Rowsell, O.M. Yaghi, Microporous Mesoporous Mater. 73 (2004) 3-14.

[18] T.K. Maji, S. Kitagawa, Pure Appl. Chem. 79 (2007) 2155-2177.

[19] K. Uemura, R. Matsuda, S. Kitagawa, J. Solid State Chem. 178 (2005) 2420-2429.

[20] S.T. Meek, J.A. Greathouse, M.D. Allendorf, Adv. Mater. 23 (2011) 249-267.

[21] G. Férey, Chem. Mat. 13 (2001) 3084-3098.

[22] O.M. Yaghi, M. O'Keeffe, N.W. Ockwig, H.K. Chae, M. Eddaoudi, J. Kim, Nature 423 (2003) 705-714.

[23] M. Maes, F. Vermoortele, L. Alaerts, S. Couck, C.E.A. Kirschhock, J.F.M. Denayer, D.E. De Vos, J. Am. Chem. Soc. 132 (2010) 15277-15285.

[24] V. Finsy, C.E.A. Kirschhock, G. Vedts, M. Maes, L. Alaerts, D.E. De Vos, G.V. Baron, J.F.M. Denayer, Chem. Eur. J. 15 (2009) 7724-7731.

[25] A.U. Ortiz, M.A. Springuel-Huet, F.X. Coudert, A.H. Fuchs, A. Boutin, Langmuir 28 (2012) 494-498.

[26] L. Hamon, P.L. Llewellyn, T. Devic, A. Ghoufi, G. Clet, V. Guillerm, G.D. Pirngruber, G. Maurin, C. Serre, G. Driver, W. van Beek, E. Jolimaitre, A. Vimont, M. Daturi, G. Férey, J. Am. Chem. Soc. 131 (2009) 17490-17499.

[27] B. Van de Voorde, A.S. Munn, N. Guillou, F. Millange, D.E. De Vos, R.I. Walton, Phys. Chem. Chem. Phys. 15 (2013) 8606-8615.

[28] C. Serre, S. Bourrelly, A. Vimont, N.A. Ramsahye, G. Maurin, P.L. Llewellyn, M. Daturi, Y. Filinchuk, O. Leynaud, P. Barnes, G. Férey, Adv. Mater. 19 (2007) 2246-2251.

[29] J.P.S. Mowat, S.R. Miller, A.M.Z. Slawin, V.R. Seymour, S.E. Ashbrook, P.A. Wright, Microporous Mesoporous Mater. 142 (2011) 322-333.

[30] H. Leclerc, T. Devic, S. Devautour-Vinot, P. Bazin, N. Audebrand, G. Férey, M. Daturi, A. Vimont, G. Clet, J. Phys. Chem. C 115 (2011) 19828-19840.

[31] C. Volkringer, T. Loiseau, N. Guillou, G. Férey, E. Elkaim, A. Vimont, Dalton Trans. (2009) 2241-2249.

[32] Y. Liu, J.H. Her, A. Dailly, A.J. Ramirez-Cuesta, D.A. Neumann, C.M. Brown, J. Am. Chem. Soc. 130 (2008) 11813-11818.

[33] C. Serre, F. Millange, C. Thouvenot, M. Nogues, G. Marsolier, D. Louer, G. Férey, J. Am. Chem. Soc. 124 (2002) 13519-13526.

[34] I. Beurroies, M. Boulhout, P.L. Llewellyn, B. Kuchta, G. Férey, C. Serre, R. Denoyel, Angew. Chem. Int. Ed. 49 (2010) 7526-7529. 
[35] G. Férey, Chem. Soc. Rev. 37 (2008) 191-214.

[36] K. Barthelet, J. Marrot, D. Riou, G. Férey, Angew. Chem. Int. Ed. 41 (2002) 281-284.

[37] F. Millange, C. Serre, G. Férey, Chem. Commun. (2002) 822-823.

[38] A. Vimont, A. Travert, P. Bazin, J.-C. Lavalley, M. Daturi, C. Serre, G. Férey, S. Bourrelly, P.L. Llewellyn, Chem. Commun. (2007) 3291-3293.

[39] G. Férey, C. Serre, Chem. Soc. Rev. 38 (2009) 1380-1399.

[40] P.L. Llewellyn, G. Maurin, T. Devic, S. Loera-Serna, N. Rosenbach, C. Serre, S. Bourrelly, P. Horcajada, Y. Filinchuk, G. Férey, J. Am. Chem. Soc. 130 (2008) 12808-12814.

[41] T. Devic, F. Salles, S. Bourrelly, B. Moulin, G. Maurin, P. Horcajada, C. Serre, A. Vimont, J.C. Lavalley, H. Leclerc, G. Clet, M. Daturi, P.L. Llewellyn, Y. Filinchuk, G. Férey, J. Mater. Chem. 22 (2012) 10266-10273.

[42] S. Bourrelly, P.L. Llewellyn, C. Serre, F. Millange, T. Loiseau, G. Férey, J. Am. Chem. Soc. 127 (2005) 13519-13521.

[43] E. Garcia-Perez, P. Serra-Crespo, S. Hamad, F. Kapteijn, J. Gascon, Phys. Chem. Chem. Phys. 16 (2014) 16060-16066.

[44] G. Ortiz, G. Chaplais, J.-L. Paillaud, H. Nouali, J. Patarin, J. Raya, C. Marichal, J. Phys. Chem. C 118 (2014) 22021-22029.

[45] G. Chaplais, A. Simon-Masseron, F. Porcher, C. Lecomte, D. Bazer-Bachi, N. Bats, J. Patarina, Phys. Chem. Chem. Phys. 11 (2009) 5241-5245.

[46] A. Boutin, D. Bousquet, A.U. Ortiz, F.X. Coudert, A.H. Fuchs, A. Ballandras, G. Weber, I. Bezverkhyy, J.P. Bellat, G. Ortiz, G. Chaplais, J.L. Paillaud, C. Marichal, H. Nouali, J. Patarin, J. Phys. Chem. C 117 (2013) 8180-8188.

[47] N.A. Ramsahye, G. Maurin, S. Bourrelly, P. Llewellyn, T. Loiseau, G. Férey, Phys. Chem. Chem. Phys. 9 (2007) 1059-1063.

[48] F. Millange, N. Guillou, R.I. Walton, J.M. Greneche, I. Margiolaki, G. Férey, Chem. Commun. (2008) 4732-4734.

[49] A.S. Munn, G.J. Clarkson, R.I. Walton, Acta Crystallogr., Sect. B 70 (2014) 11-18.

[50] S. Biswas, T. Ahnfeldt, N. Stock, Inorg. Chem. 50 (2011) 9518-9526.

[51] B. Moulin, F. Salles, S. Bourrelly, P.L. Llewellyn, T. Devic, P. Horcajada, C. Serre, G. Clet, J.-C. Lavalley, M. Daturi, G. Maurin, A. Vimont, Microporous Mesoporous Mater. 195 (2014) 197-204.

[52] S. Devautour-Vinot, G. Maurin, F. Henn, C. Serre, G. Férey, Phys. Chem. Chem. Phys. 12 (2010) 12478-12485.

[53] J.P.S. Mowat, V.R. Seymour, J.M. Griffin, S.P. Thompson, A.M.Z. Slawin, D. FairenJimenez, T. Duren, S.E. Ashbrook, P.A. Wright, Dalton Trans. 41 (2012) 3937-3941.

[54] F. Nouar, T. Devic, H. Chevreau, N. Guillou, E. Gibson, G. Clet, M. Daturi, A. Vimont, J.M. Greneche, M.I. Breeze, R.I. Walton, P.L. Llewellyne, C. Serre, Chem. Commun. 48 (2012) 10237-10239.

[55] I.J. Kang, N.A. Khan, E. Haque, S.H. Jhung, Chem. Eur. J. 17 (2011) 6437-6442.

[56] T. Devic, P. Horcajada, C. Serre, F. Salles, G. Maurin, B. Moulin, D. Heurtaux, G. Clet, A. Vimont, J.M. Greneche, B. Le Ouay, F. Moreau, E. Magnier, Y. Filinchuk, J. Marrot, J.C. Lavalley, M. Daturi, G. Férey, J. Am. Chem. Soc. 132 (2010) 1127-1136.

[57] S. Biswas, T. Remy, S. Couck, D. Denysenko, G. Rampelberg, J.F.M. Denayer, D. Volkmer, C. Detavernier, P. Van Der Voort, Phys. Chem. Chem. Phys. 15 (2013) 3552-3561.

[58] M. Pera-Titus, T. Lescouet, S. Aguado, D. Farrusseng, J. Phys. Chem. C 116 (2012) 9507 9516.

[59] T. Lescouet, E. Kockrick, G. Bergeret, M. Pera-Titus, S. Aguado, D. Farrusseng, J. Mater. Chem. 22 (2012) 10287-10293.

[60] A. Torrisi, R.G. Bell, C. Mellot-Draznieks, Cryst. Growth Des. 10 (2010) 2839-2841.

[61] T. Ahnfeldt, D. Gunzelmann, T. Loiseau, D. Hirsemann, J. Senker, G. Férey, N. Stock, Inorg. Chem. 48 (2009) 3057-3064.

[62] S. Couck, J.F.M. Denayer, G.V. Baron, T. Rémy, J. Gascon, F. Kapteijn, J. Am. Chem. Soc. 131 (2009) 6326-6327. 
[63] F. Millange, C. Serre, N. Guillou, G. Férey, R.I. Walton, Angew. Chem. Int. Ed. 47 (2008) 4100-4105.

[64] L. Hamon, C. Serre, T. Devic, T. Loiseau, F. Millange, G. Férey, G. De Weireld, J. Am. Chem. Soc. 131 (2009) 8775-8777.

[65] N.A. Ramsahye, G. Maurin, S. Bourrelly, P.L. Llewellyn, C. Serre, T. Loiseau, T. Devic, G. Férey, J. Phys. Chem. C 112 (2008) 514-520.

[66] F. Salles, A. Ghoufi, G. Maurin, R.G. Bell, C. Mellot-Draznieks, G. Férey, Angew. Chem. Int. Ed. 47 (2008) 8487-8491.

[67] N.A. Ramsahye, G. Maurin, S. Bourrelly, P.L. Llewellyn, T. Loiseau, C. Serre, G. Férey, Chem. Commun. (2007) 3261-3263.

[68] A.M. Walker, B. Civalleri, B. Slater, C. Mellot-Draznieks, F. Cora, C.M. Zicovich-Wilson, G. Roman-Perez, J.M. Soler, J.D. Gale, Angew. Chem. Int. Ed. 49 (2010) 7501-7503.

[69] A. Boutin, M.A. Springuel-Huet, A. Nossov, A. Gedeon, T. Loiseau, C. Volkringer, G. Férey, F.X. Coudert, A.H. Fuchs, Angew. Chem. Int. Ed. 48 (2009) 8314-8317.

[70] A. Boutin, F.X. Coudert, M.A. Springuel-Huet, A.V. Neimark, G. Férey, A.H. Fuchs, J. Phys. Chem. C 114 (2010) 22237-22244.

[71] F.X. Coudert, C. Mellot-Draznieks, A.H. Fuchs, A. Boutin, J. Am. Chem. Soc. 131 (2009) 11329-11331.

[72] N.A. Ramsahye, G. Maurin, S. Bourrelly, P.L. Llewellyn, T. Devic, C. Serre, T. Loiseau, G. Férey, Adsorption 13 (2007) 461-467.

[73] T.K. Trung, P. Trens, N. Tanchoux, S. Bourrelly, P.L. Llewellyn, S. Loera-Serna, C. Serre, T. Loiseau, F. Fajula, G. Férey, J. Am. Chem. Soc. 130 (2008) 16926-16932.

[74] F.-X. Coudert, M. Jeffroy, A.H. Fuchs, A. Boutin, C. Mellot-Draznieks, J. Am. Chem. Soc. 130 (2008) 14294-14302.

[75] A.V. Neimark, F.-X. Coudert, A. Boutin, A.H. Fuchs, J. Phys. Chem. Lett. 1 (2009) 445-449.

[76] F.X. Coudert, A. Boutin, A.H. Fuchs, A.V. Neimark, J. Phys. Chem. Lett. 4 (2013) 3198 3205 .

[77] A.V. Neimark, F.X. Coudert, C. Triguero, A. Boutin, A.H. Fuchs, I. Beurroies, R. Denoyel, Langmuir 27 (2011) 4734-4741.

[78] A.U. Ortiz, A. Boutin, A.H. Fuchs, F.X. Coudert, Phys. Rev. Lett. 109 (2012) 195502.

[79] A. Ghoufi, A. Subercaze, Q. Ma, P.G. Yot, Y. Ke, I. Puente-Orench, T. Devic, V. Guillerm, C. Zhong, C. Serre, G. Férey, G. Maurin, J. Phys. Chem. C 116 (2012) 13289-13295.

[80] I. Bezverkhyy, G. Ortiz, G. Chaplais, C. Marichal, G. Weber, J.-P. Bellat, Microporous Mesoporous Mater. 183 (2014) 156-161.

[81] N.C. Burtch, H. Jasuja, K.S. Walton, Chem. Rev. 114 (2014) 10575-10612.

[82] S. Bourrelly, B. Moulin, A. Rivera, G. Maurin, S. Devautour-Vino, C. Serre, T. Devic, P. Horcajada, A. Vimont, G. Clet, M. Daturi, J.C. Lavalley, S. Loera-Serna, R. Denoyel, P.L. Llewellyn, G. Férey, J. Am. Chem. Soc. 132 (2010) 9488-9498.

[83] S. Devautour-Vinot, G. Maurin, F. Henn, C. Serre, T. Devic, G. Férey, Chem. Commun. (2009) 2733-2735.

[84] P.L. Llewellyn, S. Bourrelly, C. Serre, Y. Filinchuk, G. Férey, Angew. Chem. Int. Ed. 45 (2006) 7751-7754.

[85] M.G. Goesten, J. Juan-Alcaniz, E.V. Ramos-Fernandez, K. Gupta, E. Stavitski, H. van Bekkum, J. Gascon, F. Kapteijn, J. Catal. 281 (2011) 177-187.

[86] S. Biswas, S. Couck, D. Denysenko, A. Bhunia, M. Grzywa, J.F.M. Denayer, D. Volkmer, C. Janiak, P. Van Der Voort, Microporous Mesoporous Mater. 181 (2013) 175-181.

[87] J. Liu, F. Zhang, X.Q. Zou, G.L. Yu, N. Zhao, S.J. Fan, G.S. Zhu, Chem. Commun. 49 (2013) 7430-7432.

[88] F. Salles, S. Bourrelly, H. Jobic, T. Devic, V. Guillerm, P. Llewellyn, C. Serre, G. Férey, G. Maurin, J. Phys. Chem. C 115 (2011) 10764-10776.

[89] V. Haigis, F.X. Coudert, R. Vuilleumier, A. Boutin, Phys. Chem. Chem. Phys. 15 (2013) 19049-19056.

[90] F. Paesani, Mol. Sim. 38 (2012) 631-641.

[91] N. Guillou, F. Millange, R.I. Walton, Chem. Commun. 47 (2011) 713-715. 
[92] G. Férey, Z. Anorg. Allg. Chem. 638 (2012) 1897-1909.

[93] D.S. Coombes, F. Cora, C. Mellot-Draznieks, R.G. Bell, J. Phys. Chem. C 113 (2009) 544552 .

[94] J. Cirera, J.C. Sung, P.B. Howland, F. Paesani, J. Chem. Phys. 137 (2012) 054704.

[95] F. Paesani, J. Phys. Chem. C 117 (2013) 19508-19516.

[96] J. Canivet, A. Fateeva, Y. Guo, B. Coasne, D. Farrusseng, Chem. Soc. Rev. 43 (2014) 55945617.

[97] F.X. Coudert, A.U. Ortiz, V. Haigis, D. Bousquet, A.H. Fuchs, A. Ballandras, G. Weber, I. Bezverkhyy, N. Geolfroy, J.P. Bellat, G. Ortiz, G. Chaplais, J. Patarin, A. Boutin, J. Phys. Chem. C 118 (2014) 5397-5405.

[98] M.-H. Simonot-Grange, A. Elm'Chaouri, G. Weber, P. Dufresne, F. Raatz, J.-F. Joly, Zeolites 12 (1992) 155-159.

[99] J.W. McBain, A.M. Bakr, J. Am. Chem. Soc. 48 (1926) 690-695.

[100] M.H. Simonot-Grange, Clays Clay Miner. 27 (1979) 423-428.

[101] J. Rodriguez-Carvajal, Reference Guide for the Computer Program Fullprof, Laboratorie León Brillouin, CEA-CNRS, Saclay, France, 2001.

[102] A. Le Bail, H. Duroy, J.L. Fourquet, Mat. Res. Bul. 23 (1988) 447-452.

[103] G. Weber, F. Benoit, J.-P. Bellat, C. Paulin, P. Mougin, M. Thomas, Microporous Mesoporous Mater. 109 (2008) 184-192.

[104] A. Ballandras, Contribution and limitation of infrared spectroscopy technique to understand physisorption processes on MFI zeolites, Université de Bourgogne, Thesis, Dijon, 2011.

[105] A. Ballandras, G. Weber, C. Paulin, J.-P. Bellat, M. Rotger, J. Chem. Phys. 139 (2013) 091103.

[106] V.K. Pecharsky, P.Y. Zavalij, Fundamentals of powder diffraction and structural characterization of materials, second ed., Springer, New York, 2009.

[107] E.B.J. Wilson, Phys. Rev. 45 (1934) 706-714. 


\section{Figure captions}

\section{Fig. 1.}

Water adsorption isotherms obtained in the low pressure range at $298 \mathrm{~K}$ on Ga-MIL-53 outgassed under vacuum at $298 \mathrm{~K}$ (blue curve; np_empty phase at zero loading) and $553 \mathrm{~K}$ (red curve; lp_empty phase at zero loading) (closed symbols: adsorption; open symbols: desorption; arrows: mark points where in situ X-ray measurements were performed in the range of low pressure).

\section{Fig. 2.}

XRD patterns of the $l p \_e m p t y$ form of Ga-MIL-53 exposed to increasing water vapor pressures at $298 \mathrm{~K}$ (under vacuum: red curve a; $0.2 \mathrm{hPa}$ : green cuve b; $0.5 \mathrm{hPa}$ : magenta curve c; $0.8 \mathrm{hPa}$ : purple curve d; $15 \mathrm{hPa}$ : blue curve e; A: (110) peak for the int phase; $\mathrm{B}$ : (110) peak for the $n p \_\mathrm{H}_{2} \mathrm{O}$ phase; $\mathrm{C}$ : (110) peak for the lp_empty phase).

\section{Fig. 3.}

Adsorption enthalpies of water vapor on Ga-MIL-53 outgassed under vacuum at $298 \mathrm{~K}$ (blue curve; $n p \_e m p t y$ phase at zero loading) and $553 \mathrm{~K}$ (red curve; lp_empty phase at zero loading).

\section{Fig. 4.}

Dependence of the position of $v_{\mathrm{as}} \mathrm{CO}_{2}(\mathrm{a})$ and $\delta \mathrm{CH}(\mathrm{b})$ (referenced as $v 18 \mathrm{~A}$ in the Wilson [107] notation) in plane deformation modes of the terephthalate ligands of Ga-MIL-53 outgassed under vacuum at $298 \mathrm{~K}$ (blue symbols; $n p \_e m p t y$ phase at zero loading) and 553 $\mathrm{K}$ (red symbols; lp_empty phase at zero loading), upon water adsorption at $298 \mathrm{~K}$. 


\section{Fig. 5.}

Chart showing the pressure ranges where some characteristic vibrational bands of the adsorbent are shifted (infrared spectroscopic data) and the nature of the phases formed (XRD data) along the water adsorption isotherm obtained on the large pore (lp_empty) form of Ga-MIL-53 at $298 \mathrm{~K}$ (P1: the int phase; P2: the $n p_{-} H_{2} O$ phase; M: mixture of P1 and P2; closed symbols: adsorption; open symbols: desorption). 


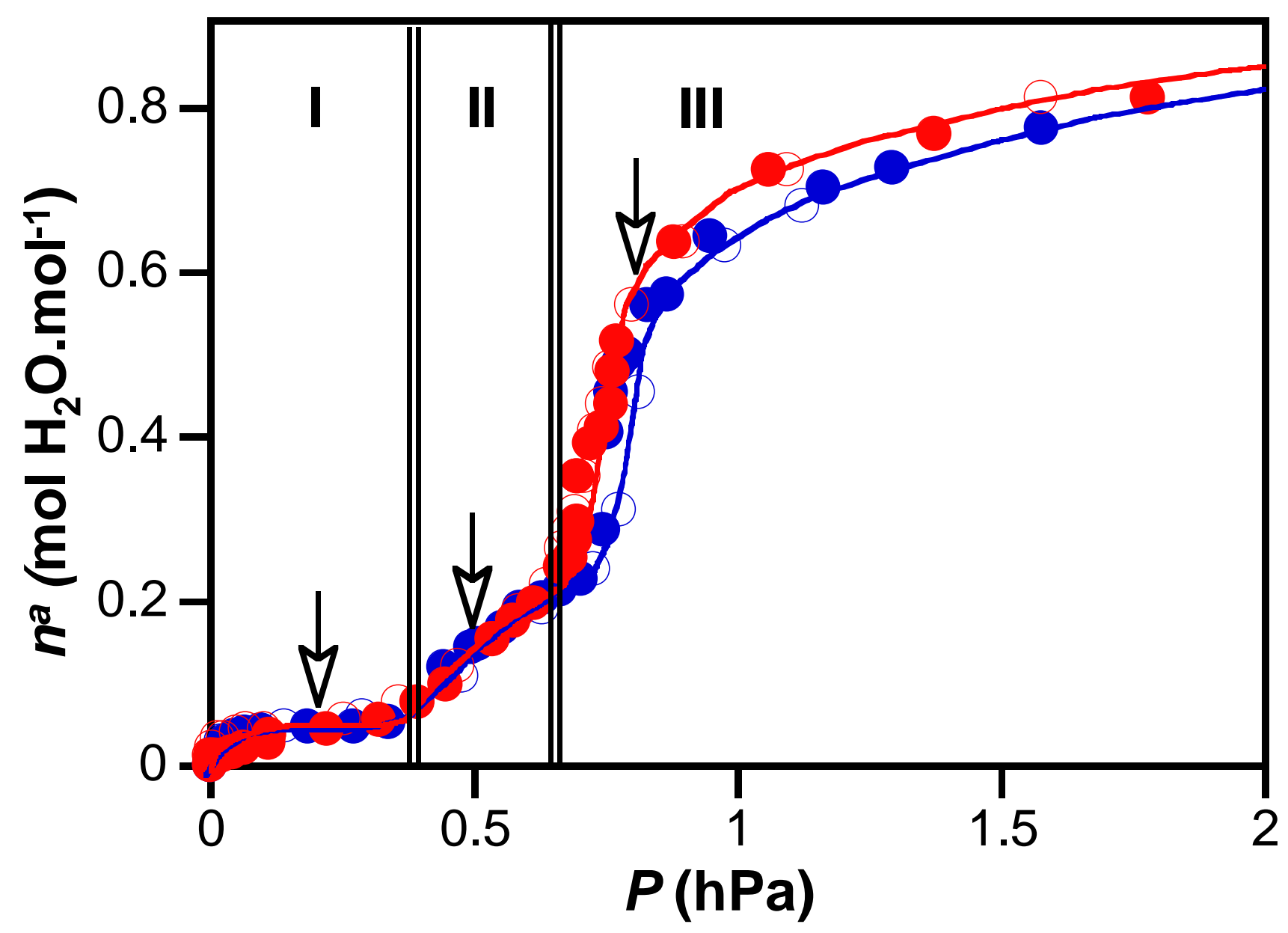




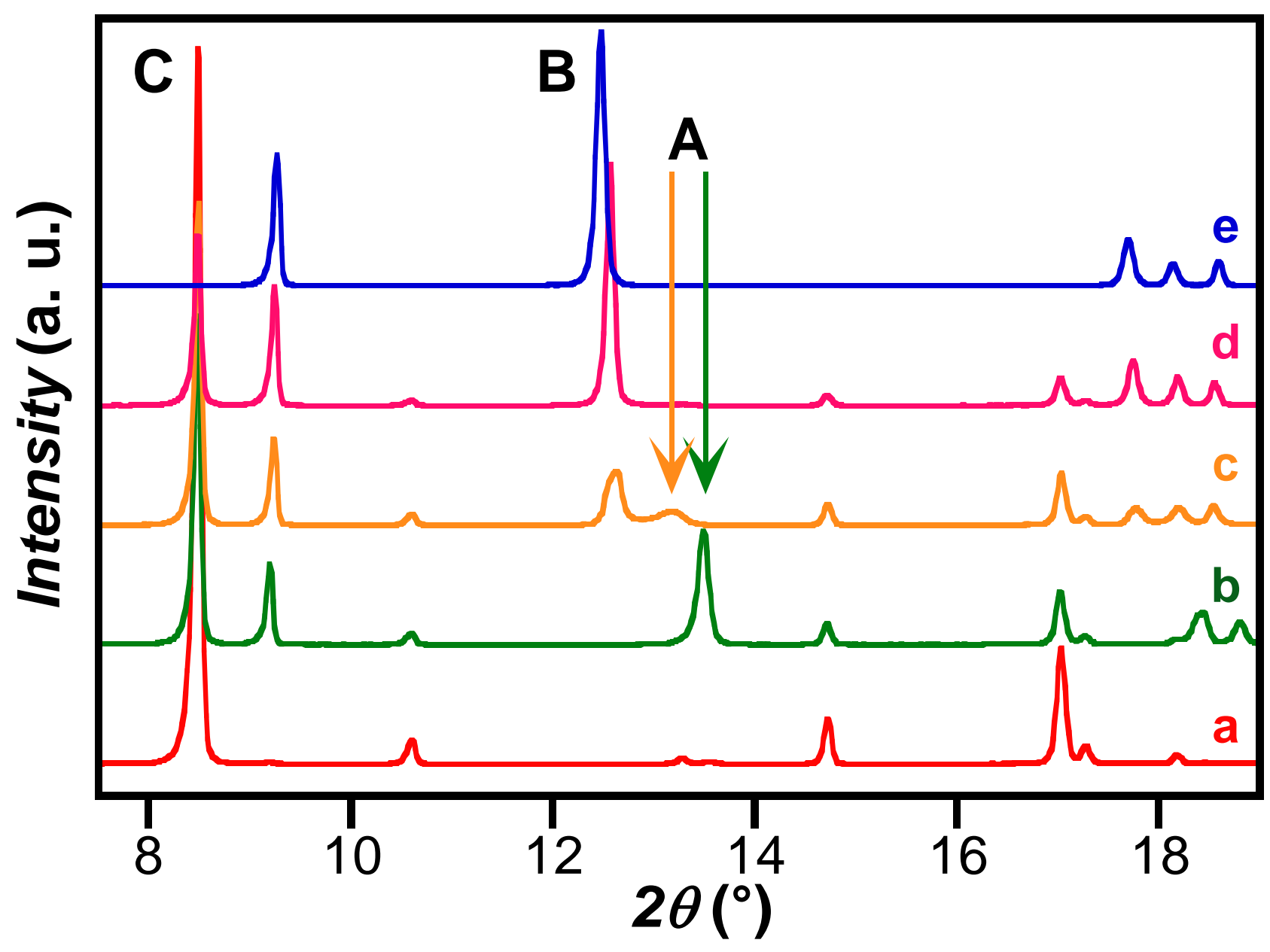




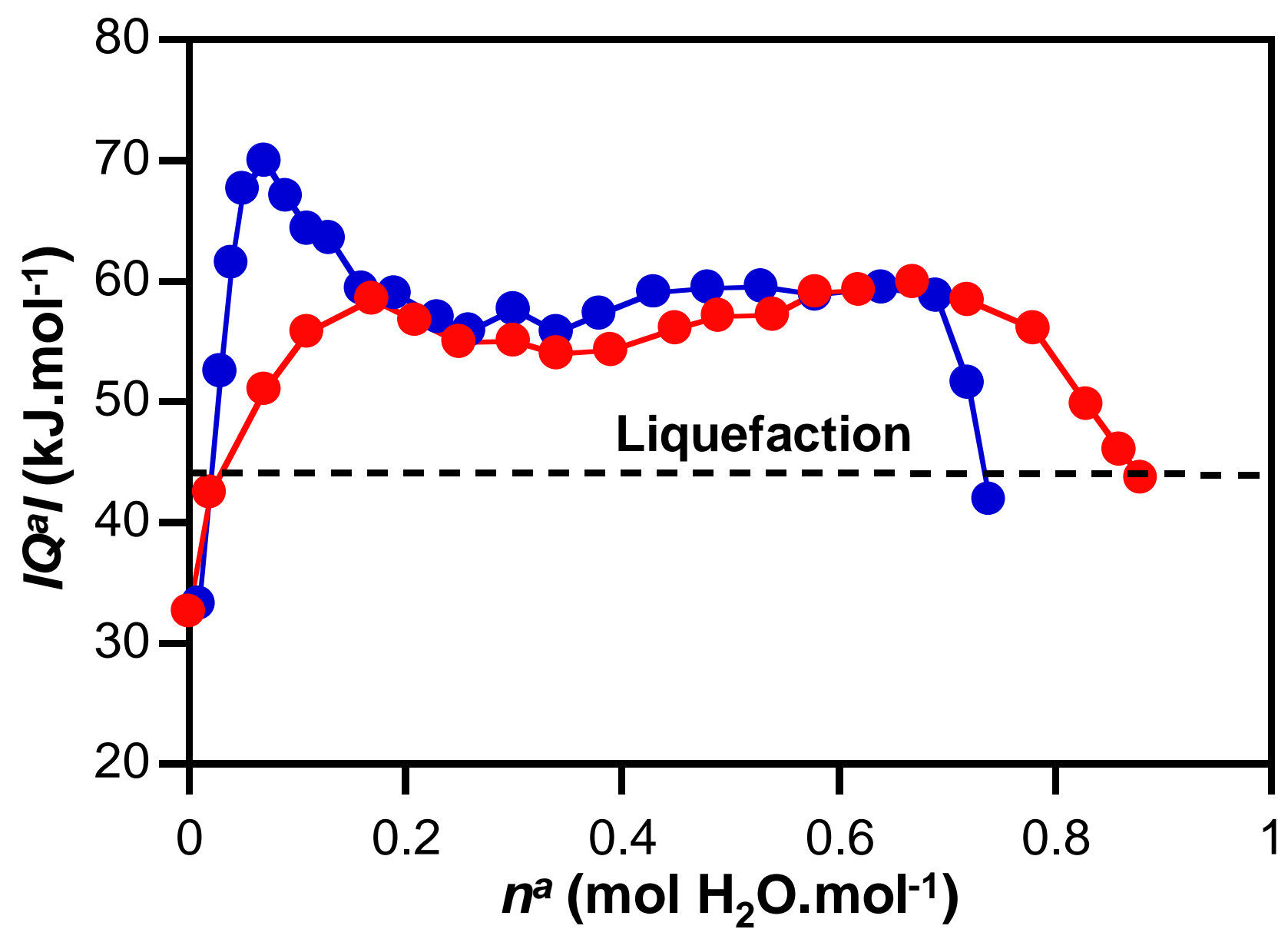



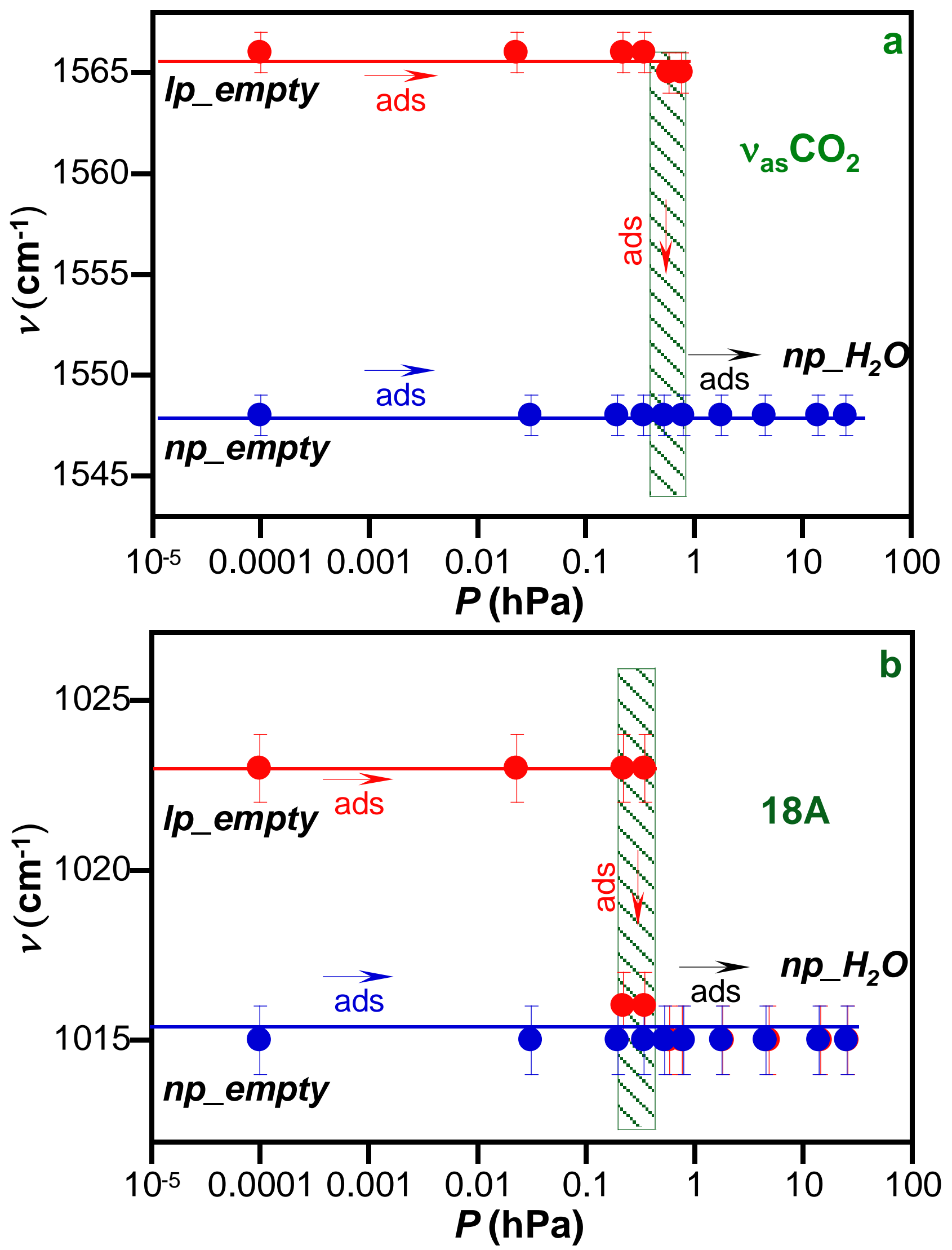


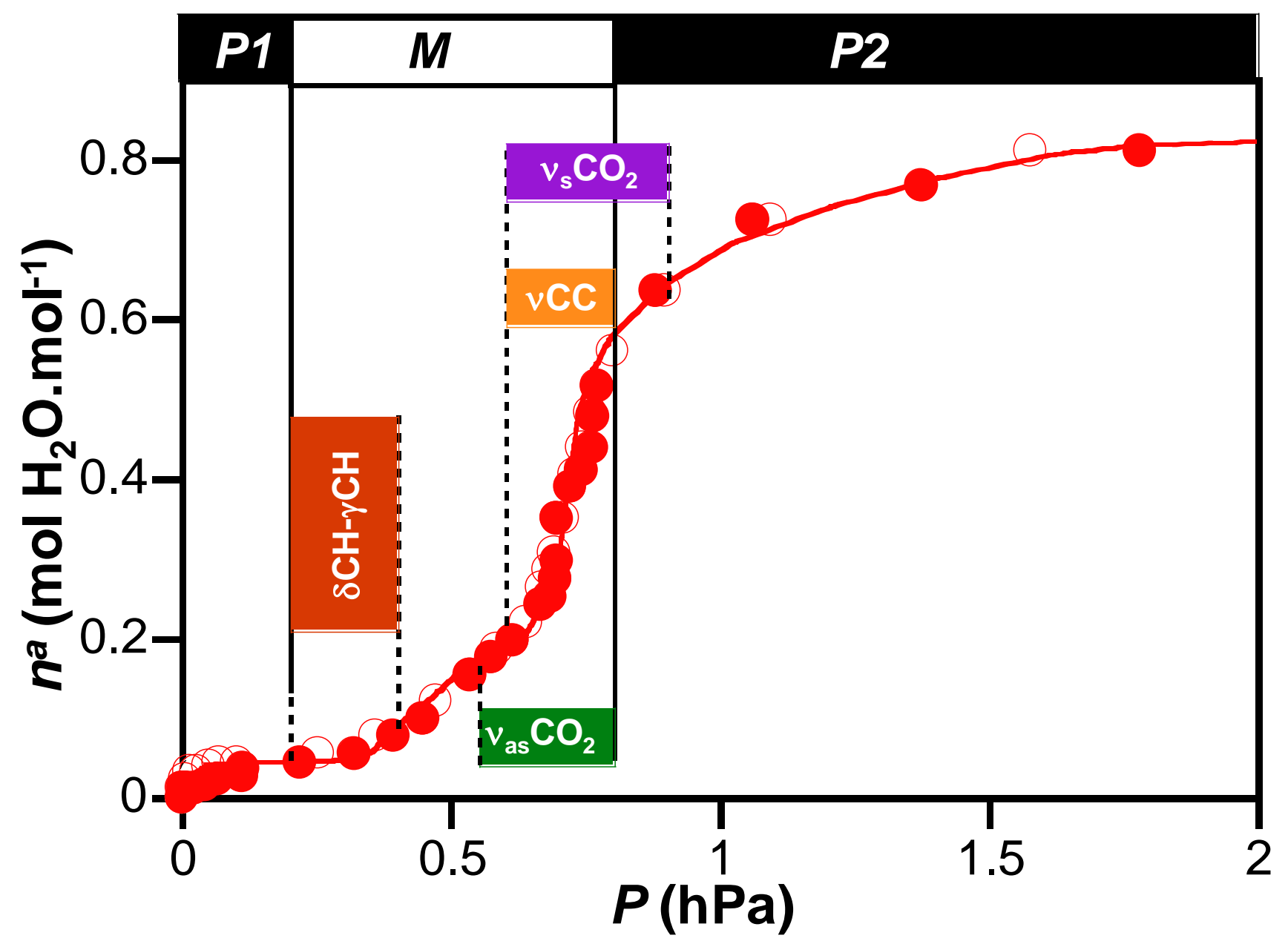




\section{Table 1}

Characterization of the phases formed during water adsorption on the lp_empty form of GaMIL-53 at $298 \mathrm{~K}\left(a, b, c \beta\right.$ : unit cell parameters $\left.{ }^{\$}\right)$

\begin{tabular}{|c|c|c|c|c|c|c|c|c|c|c|c|c|c|}
\hline \multirow[t]{2}{*}{$\begin{array}{l}\text { Water } \\
\text { pressure } \\
(\mathrm{hPa})\end{array}$} & \multirow{2}{*}{$\begin{array}{l}\text { Percentage* } \\
\text { of } \\
\text { lp_empty } \\
\text { phase } \\
(\%)\end{array}$} & \multicolumn{4}{|c|}{ lp_empty } & \multicolumn{4}{|c|}{ int } & \multicolumn{4}{|c|}{$n p_{-} \mathrm{H}_{2} \mathrm{O}$} \\
\hline & & $\begin{array}{l}a \\
(\mathrm{~nm})\end{array}$ & $\begin{array}{l}b \\
(\mathrm{~nm}) \\
\end{array}$ & $\begin{array}{l}c \\
(\mathrm{~nm}) \\
\end{array}$ & $\begin{array}{l}\beta \\
\left(^{\circ}\right) \\
\end{array}$ & $\begin{array}{l}a \\
(\mathrm{~nm})\end{array}$ & $\begin{array}{l}b \\
(\mathrm{~nm}) \\
\end{array}$ & $\begin{array}{l}c \\
(\mathrm{~nm})\end{array}$ & $\begin{array}{l}\beta \\
\left(^{\circ}\right) \\
\end{array}$ & $\begin{array}{l}a \\
(\mathrm{~nm})\end{array}$ & $\begin{array}{l}b \\
(\mathrm{~nm}) \\
\end{array}$ & $\begin{array}{l}c \\
(\mathrm{~nm})\end{array}$ & $\begin{array}{l}\beta \\
\left(^{\circ}\right) \\
\end{array}$ \\
\hline $0 * *$ & 100 & 1.665 & 1.330 & 0.673 & 90.0 & - & - & - & - & - & - & - & - \\
\hline 0.2 & 48 & 1.667 & 1.332 & 0.674 & 90.0 & 1.971 & 0.697 & 0.678 & 102.9 & - & - & - & - \\
\hline 0.5 & 46 & 1.666 & 1.331 & 0.673 & 90.0 & 1.957 & 0.714 & 0.673 & 101.8 & 1.977 & 0.753 & 0.668 & 103.9 \\
\hline 0.8 & 24 & 1.653 & 1.337 & 0.673 & 90.0 & - & - & - & - & 1.968 & 0.756 & 0.668 & 104.0 \\
\hline $15^{* * *}$ & 0 & - & - & - & - & - & - & - & - & 1.966 & 0.764 & 0.667 & 103.9 \\
\hline
\end{tabular}

${ }^{\$}$ Precision on the value of the unit cell parameters estimated to be $0.005 \mathrm{~nm}$.

* See text for the details of the calculations (standard deviation: $1 \%$ )

** Under vacuum

*** Fully hydrated phase ( $n p_{-} \mathrm{H}_{2} \mathrm{O}$ with 0.9 molecule of $\mathrm{H}_{2} \mathrm{O}$ per $\mathrm{Ga}$ atom) 